\title{
Faktor Risiko Stunting pada anak di Negara Berkembang
}

\section{Risk Factors of Child Stunting in Developing Countries}

\author{
Indah Budiastutik*1, Muhammad Zen Rahfiludin ${ }^{2}$
}

\begin{abstract}
ABSTRAK
Latar Belakang: Masalah stunting (stunting) yang terjadi di Negara Berkembang seperti Indonesia masih tinggi yaitu 30,8\% masih di atas dunia yaitu $22,2 \%$. Stunting di sub sahara Afrika $34,5 \%$, di Ethiopia $52,4 \%$, prevalensi stunting di Congo $40 \%$. Word Health Organization sudah menentukan bahwa terjadinya masalah gizi suatu negara sebaiknya kurang dari $20 \%$. Stunting memiliki risiko gangguan pertumbuhan, perkembangan dan penyakit degeneratif pada usia dewasa nanti.

Tujuan: Review ini bertujuan untuk mengidentifikasi faktor risikos apa saja yang dapat menentukan terjadinya stunting anak di Negara berkembang.

Ulasan: Berdasarkan dari beberapa hasil penelitian menyebutkan bahwa salah satu penyebab stunting pada anak adalah karena tidak terpenuhinya gizi yang baik pada kurun waktu yang panjang dan sering kali tidak disadari oleh orang tuanya sehingga setelah anak usia di atas 2 tahun baru terlihat bahwa anaknya mengalami stunting. Berdasarkan hasil literatur review menunjukkan bahwa faktor risiko terjadinya stunting adalah panjang lahir berisiko 16,43 kali, pendidikan ibu yang rendah berisiko 3,27 kali, serta anak yang tinggal di desa berisiko 2,45 kali, BBLR berisiko 4,5 kali, tidak ANC berisiko 3,4 kali, tidak imunisasi berisiko 6,38 kali, dan tidak ASI Eksklusif berisiko 4,0 kali adalah merupakan faktor risiko stunting anak di negara berkembang.

Kesimpulan: Hasil sintesis ini secara konsisten yang menjadi faktor risikos terjadinya stunting pada anak di negara berkembang adalah tidak diberikan ASI eksklusif, sosial ekonomi, berat bayi lahir rendah, panjang lahir, pendidikan ibu rendah, penyakit infeksi.
\end{abstract}

Kata kunci: stunting, faktor risiko, anak, negara berkembang

\section{ABSTRACT}

Background: The problem of stunting occurs in developing countries including Indonesia. In Indonesia the prevalence of child stunting is $30.8 \%$, still above the world prevalence, which is $22.2 \%$. The prevalence of stunting in sub-Saharan Africa is $34.5 \%$, in Ethiopia is $52.4 \%$, and the prevalence of stunting in Congo is $40 \%$. While WHO stipulates that nutrition problems should not exceed 20\%. Stunting could inhibit linear growth, development and degenerative diseases later in adulthood.

Objective: This review discussed the risk factors of child stunting in developing countries.

Discusion: One of the causes of increased stunting in children was due to inadequate nutritional intake in a long period. Stunting was often not realized by parents and only visible after the age of 2 due to low stature. Based on the results of the literature review the likelihood of stunting in developing country were: 16.43 times morelikely due to low birth length, 3.27 times higher due to maternal education, 2.45 times higher if the children were living in rural area, 4.5 times higher due to low birth weight, no risk Antenatal Care increase the risk 3.4 times, 6.38 times higher due to no immunization, and no exclusive breastfeeding increase the risk of stunting 4.0 times.

Conclusion: The risk factor for child stunting in developing countries are exclusive breastfeeding, socioeconomic, low birth weight, length of birth, low maternal education, infectious disease.

Keywords: stunting, risk factors, children, developing countries

*Koresponden:

indahbudiastutik@unmuhpnk.ac.id

${ }^{1}$ Fakultas IImu Kesehatan Universitas Muhammadiyah Pontianak, Kalimantan Barat

${ }^{2}$ Fakultas Kesehatan Masyarakat Universitas Diponegoro Semarang 


\section{PENDAHULUAN}

Keadaan tubuh yang pendek dan sangat pendek hingga melampaui defisit -2 SD di bawah median panjang atau tinggi badan anak disebut Stunting ${ }^{1}$. Secara global prevalensi $22,9 \%$ atau 154,8 juta anak di bawah usia 5 tahun menderita stunting 2. Masalah stunting dialami oleh sebagian besar anak di Negara miskin dan berkembang seperti Indonesia. Prevalensi stunting yang terjadi di Afrika selatan sebesar $18,6 \%{ }^{3}$, di Ethiopia sebesar 26,4\% 4, di Nigeria (22.2\%) ${ }^{5}$. Sedangkan terdapat 6 juta di Amerika Latin dan karibia². Prevalensi di Asia seperti India (38,4\% 2015), Pakistan (45\% 2012), Bangladesh (36,1\% 2014), Malaysia $(20,7 \%$ 2016),Philipina, Thailand (10,5\% 2017) 6 , Indonesia $30,8 \%{ }^{7}$. Hasil penelitian pendahuluan membuktikan bahwa faktor keturunan berperan sebesar $15 \%$, penyebab utama stunting adalah kurangnya asupan zat gizi, hormon pertumbuhan dan adanya penyakit infeksi ${ }^{89}$. Adapun Variabel pengaruh paparan asap rokok maupun polusi asap juga berpengaruh terhadap kejadian stunting namun belum banyak dilakukan penelitian yang lebih jauh 10

Dampak jangka panjang hingga berulang dalam siklus kehidupan pada balita stunting terjadi pada titik kritis pada masa 1000 Hari Pertama Kehidupan sebagai awal terjadinya pertumbuhan ${ }^{11}$. Kurang gizi sebagai penyebab langsung, khususnya pada balita berdampak jangka pendek meningkatnya morbiditas. Stunting ini bersifat kronis, sehingga dapat mempengaruhi fungsi kognitif anak di mana tingkat kecerdasan yang rendah dan berdampak pada kualitas sumberdaya manusia.

Masalah Stunting yang terjadi pada Negara berkembang seperti Indonesia akan menjadi masalah kesehatan masyarakat yang harus dilakukan penanganan secara serius dan berkesinambungan. Hasil Riskesdas menunjukkan bahwa masalah Stunting yang terjadi relatif tetap sekitar $36.8 \%$ tahun 2007 dan mencapai $37,2 \%$ tahun 2013, Sementara tahun 2018 menurun 6,4\% menjadi 30,8\%. Sedangkan prevalensi yang terjadi di Negara berkembang lainya seperti Afrika $18,6 \%{ }^{12}$, Ethiopia $26,4 \%{ }^{5}$, Nigeria $(22,2 \%)$, india $38,4 \%$, Pakistan 45\%, Bangladesh $36,1 \%$, Malaysia $20 \%$ Thailand $10,5 \%$.

Berdasarkan hasil riset terdahulu dinyatakan bahwah faktor risiko kejadian stunting adalah berat badan lahir, ASI tidak eksklusif serta pemberian makanan 'pendamping ASI yang tidak optimal ${ }^{13}$ Stunting yang pada masa balita dapat berlanjut dan berisiko tumbuh pendek pada usia remaja. Anak yang stunting pada usia dini (0-2 tahun) dan tetap pendek pada usia 4-6 tahun memiliki risiko 27 kali untuk tetap pendek sebelum memasuki usia pubertas; sebaliknya anak yang pertumbuhannya normal pada usia dini dapat mengalami growth faltering pada usia 4-6 tahun memiliki risiko 14 kali tumbuh pendek pada usia prapubertas. Oleh karena itu, intervensi tetap dibutuhkan bahkan setelah melewati 1000 Hari Pertama Kehidupan (HPK) untuk mencegah pertumbuhan stunting yang makin meningkat. ${ }^{14}$
Oleh karena itu masalah stunting menarik untuk dibahas karena dampak jangka panjang terkait dengan kualitas sumberdaya manusia yang mengalami gangguan penyakit degeneratif di masa yang akan datang, dampak jangka menengah terkait dengan intelektualitas dan kemampuan kognitif yang rendah dan dampak jangka pendek yang serius adalah risiko morbiditas dan mortalitas pada bayi dan balita.

\section{DISKUSI}

Upaya percepatan perbaikan gizi merupakan hal yang serius untuk Indonesia maupun Global dan semua negara yang memiliki masalah gizi (stunting). Upaya yang di inisiasi oleh World Health Assembly ${ }^{15}$ memiliki target dalam upaya penurunan prevalensi stunting antara lain untuk menurunkan prevalensi stunting, wasting dan mencegah terjadinya overweight pada balita, menurunkan prevalensi anemia pada wanita usia subur, menurunkan prevalensi bayi berat lahir rendah (BBLR), meningkatkan cakupan ASI eksklusif. Indonesia sebagai anggota PBB dengan prevalensi stunting yang tinggi memiliki berkomitmen kuat dalam upaya percepatan perbaikan gizi di masyarakat dengan melaksanakan 'Scaling Up Nutrition (SUN)'.

Arah perbaikan gizi di Indonesia sesuai dengan Undang-Undang Kesehatan nomor 36 tahun 2009 tentang Kesehatan adalah meningkatkan mutu gizi perorangan dan masyarakat melalui beberapa strategi : perbaikan pola konsumsi dengan gizi seimbang; perilaku sadar gizi, aktivitas fisik, dan kesehatan peningkatan akses dan mutu pelayanan gizi yang sesuai dengan kemajuan ilmu dan teknologi serta peningkatan sistem kewaspadaan pangan dan gizi. Kebijakan di bidang pangan untuk perbaikan status gizi masyarakat ditetapkan dalam Undang- Undang tentang Pangan nomor 18 tahun 2012 yang mendorong Pemerintah Pusat dan Pemerintah Daerah untuk menyusun Rencana Aksi Pangan dan Gizi setiap 5 (lima) tahun.

Regulasi tutunan dari Undang-undang tersebut adalah terbitnya Perpres No. 5 tahun 2010 tentang RPJM (2010-2014) menyebutkan, arah Pembangunan Pangan dan Gizi yaitu meningkatkan ketahanan pangan dan status kesehatan dan gizi masyarakat. Adapun dalam Inpres No.3 tahun 2010 ditegaskan kembali tentang Penyusunan Rencana Aksi Nasional Pangan dan Gizi (RAN-PG) 2011-2015 serta Rencana Aksi Daerah Pangan dan Gizi (RAD-PG) 2011-2015 di 33 provinsi ${ }^{16}$. Kerjasama Lintas Negara melaui PBB dalam mewujudkan pembangunan secara berkesinambungan hingga tahun 2030 dicanangkan mulai 21 Oktober 2015. Dalam upaya mendukung percepatan tersebut, disusunlah instrument pendukung kebijakan dalam percepatan perbaikan gizi dan upaya implementasi harsu dilakukan bersama dan terorganisir agar dapat diterapkan disetiap tingkatan oleh setiap pemangku kepentingan yang terlibat. Terbitnya Perpres ini akan membuat upaya yang dilaksanakan lebih konkrit, fokus pada 1000 HPK dan mendorong integrasi kegiatan lintas program (upaya spesifik) maupun lintas sektoral (upaya sensitif) semua pemangku kepentingan. ${ }^{17}$

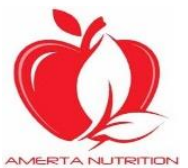

(C)2019. Budiastutik dan Rahfiludin. Open access under CC BY - SA license.

Received: 10-07-2019, Accepted: 28-08-2019, Published online: 09-9-2019. doi: 10.20473/amnt.v3.i3.2019.122-129, Joinly Published by IAGIKMI \& Universitas Airlangga 
Dengan adanya peraturan dan kebijakan dalam penanganan stunting ini maka dapat diketahui berdasarkan hasil beberapa penelitian yang meneliti tentang faktor determinan terjadinya stunting, bahwa stunting di Indonesia dapat terjadi karena beberapa faktor yang menjadi penyebab antara lain pemberian ASI tidak eksklusif, status social ekonomi rumah tangga yang rendah, kelahiran premature, panjang lahir pendek dan pendidikan ibu yang rendah serta anak yang tinggal di desa, pada rumah tangga yang kumuh, sanitasi lingkungan yang buruk, budaya adalah merupakan faktor risikos terjadinya stunting pada anak-anak di Indonesia. Sedangkan faktor risikos stunting yang secara konsisten berdasarkan penemuan dan hasil riset-riset yang telah dilakukan di Negara-negara berkembang adalah :

Pemberian ASI tidak Eksklusif, bahwa dengan pemberian ASI Eksklusif sangat erat dengan penurunan kejadian stunting pada anak. Oleh Karena itu anak yang tidak mendapatkan ASI secara eksklusif akan berisiko mengalami stunting ${ }^{18}$, dua analisis terbaru bahwa bayi yang disapih sebelum berusia 6 bulan akan lebih berisiko terkena stunting ${ }^{19}$ pemberian ASI pada usia 0-5 bulan akan berkontribusi dalam menunurunkan kejadian stunting pada anak ${ }^{18}$, penelitian di Ethiopia anak yang diberikan ASI $<2$ tahun berisiko 3,2 kali mengalami stunting 12 Penelitian di Indonesia Bayi yang tidak mendapatkan ASI berisiko stunting 20-22 23,24, Penelitian di Mozambique bahwa durasi pemberian ASI berhubungan dengan stunting 25 .

Status Sosial Ekonomi Keluarga, hasi pendapatan keluarga merupakan salah satu indikator sosial ekonomi keluarga lebih baik sehingga keluarga dapat mencukupi dan memenuhi kebutuhan konsumsi gizi dalam keluarga, didukung hasil penelitian yang menyatakan bahwa pekerjaan dan pendapatan orang tua sebagai petani berisiko anak mengalami stunting ${ }^{26}$ pendapatan keluarga yang rendah berisiko terhadap stunting 27 penelitian yang dilakukan di 3 propinsi di Indonesia yaitu Bali, Jawa Barat dan NTT faktor risiko stunting salah satunya adalah pendapatan ayah yang rendah ${ }^{28}$ Hasil riset yang dilakukan di Kota Semarang menunjukkan bahwa tingkat social ekonomi keluarga yang rendah berisiko 11 kali mengalami stunting ${ }^{29}$, Hasil riset di Propinsi Maluku menunjukkan variabel pendapatan keluarga yang rendah menjadi faktor risiko stunting ${ }^{30}$ penelitian yang dilakukan di India, Nepal, Ethiopia, dan Madagascar menyatakan bahwa faktor social ekonomi yang terkait dengan pendapatan dan kemiskinan berhubungan dengan stunting ${ }^{31-35}$ ibu tidak bekerja juga berisiko 3,11 kali mengalami stunting .

Kelahiran bayi yang mengalami Berat Bayi Lahir Rendah $^{36}$, dan bayi yang lahir secara premature memiliki risiko secara konsisten mengalami stunting di Indonesia 22-24,37. Hasil penelitian menunjukkan bahwa bayi yang lahir dengan BBLR memiliki risiko 1,74 kali mengalami hambatan pertumbuhan $T B / \mathrm{U}^{38}$ berdasarkan hasil riset yang lain bahwa bayi yang dilahirkan kondisi BBLR adalah faktor risiko yang paling paling menentukan kejadian stunting pada anak. Hasil penelitian di Hulu Sungai Utara bayi dengan BBLR berisiko 5,87 kali mengalami stunting pada anak baduta 39. Penelitian yang ditemukan di Brebes bahwa Berat Bayi Lahir Rendah berisiko 6,63 kali mengalami stunting 21. Penelitian yang di lakukan di Rwanda, Ethiopia, Burundi, Iran dan Nepal secara konsisten juga menyatakan bahwa BBLR berisiko stunting $35,36,40,41$.penelitian di Semarang juga menyebutkan bahwa Berat Bayi Lahir Rendah berisiko 11,5 kali mengalami stunting ${ }^{42}$.

Panjang lahir, penelitian yang dilakukan di Kulon Progo bahwa panjang lahir pada bayi jika kurang dari 48 $\mathrm{cm}$ akan berisiko mengalami stunting pada waktu yang akan datang 27 berdasarkan penelitian di india bayi yang lahir dengan panjang badan kecil berisiko stunting ${ }^{43}$, penelitian di Depok diketahui bahwa panjang lahir bayi pendek berisiko terhadap anak stunting dikemudian hari $^{44}$, penelitian yang dilakukan Friska dkk menemukan bahwa panjang lahir pendek berisiko 16,4 kali mengalami stunting 45 .

Pendidikan ibu, bahwa pendidikan ibu sangat menentukan kesehatan anak, karena dengan pendidikan yang memadai ibu akan lebih selektif dan kreatif dalam memberikan makanan yang baik dan bergizi pada anaknya. Hasil penelitian menunjukkan bahwa pendidikan ibu yang rendah berisiko 1,6 kali berisiko mengalami stunting ${ }^{46}$ penelitian yang dilakukan di Indonesia secara konsisten bahwa pendidikan ibu berpengaruh terhadap stunting ${ }^{47}$. Riset yang dilakukan di Banjar baru diperoleh bahwa variable pendidikan ibu yang rendah memiliki risiko 5,1 kali mengalami stunting pada anaknya ${ }^{39}$. Berdasarkan hasil penelitian di negara berkembang lainya secara konsisten menyatakan bahwa pendidikan ibu berisiko mengalami stunting 5,35,36,48-50.

Penyakit infeksi, berdasarkan kerangka konsep WHO penyakit infeksi yang sering terjadi pada anak yang mengalami stunting adalah seperti diare, kecacingan, peradangan, malaria, dan gangguan saluran pernafasan. Ditemukan yang paling berisiko mengalami stunting adalah penyakit diare, hal ini terjadi kemungkinan anak belum mendapatkan imunisasi lengkap. Berdasarkan hasil penelitian di daerah miskin dan pedesaan bahwa penyakit infeksi menular seperti diare berisiko terhadap stunting ${ }^{51}$ hasil penelitian di Ethiopia menunjukkan anak yang menderita diare berisiko 6,3 kali mengalami stunting ${ }^{52}$ hasil penelitian Hywot Yisak et al bahwa anak yang mengalami diare berisiko 2,4 kali mengalami stunting ${ }^{33}$, penelitian Blessing et al menyatakan bahwa balita yang mengalami diare 2 minggu terakhir menjadi determinan terjadinya stunting ${ }^{53}$ dan beberapa penelitian membuktikan bahwa penyakit infeksi menjadi faktor risiko terjadinya stunting. ${ }^{24,33,52,54}$

Selanjutnya dapat di lihat beberapa perbedaan hasil penelitian tentang faktor risiko stunting di Indonesia dan negara berkembang lainnya di bawah ini 
Tabel 1. Beberapa artikel hasil penelitian terkait faktor risikos terjadinya stunting terangkum dalam daftar jurnal rujukan

\begin{tabular}{|c|c|c|c|c|}
\hline $\begin{array}{c}\text { Nama } \\
\text { peneliti }\end{array}$ & Judul Penelitian & Populasi & Metode & Hasil dan Kesimpulan \\
\hline $\begin{array}{l}\text { Alphonse et } \\
\text { al, } \\
2015, \text { Rwanda }\end{array}$ & $\begin{array}{l}\text { Faktor risikos for } \\
\text { stunting among } \\
\text { children under five } \\
\text { years: a cross- } \\
\text { sectional } \\
\text { population-based } \\
\text { study in Rwanda } \\
\text { using the } 2015 \\
\text { Demographic and } \\
\text { Health Survey }\end{array}$ & $\begin{array}{l}3594 \\
\text { anak,bawah } 5 \\
\text { tahun }\end{array}$ & $\begin{array}{l}\text { A Cross- } \\
\text { Sectional }\end{array}$ & $\begin{array}{l}\text { Berat lahir rendah }(2,12) \text {, pendidikan ibu } \\
\text { rendah }(3,27) \text {, ibu yang buta huruf }(2,00) \text {, } \\
\text { tidak minum obat cacing saat hamil }(1,29), \mathrm{RT} \\
\text { miskin }(1,45) \text {. } \\
\text { Kesimpulan : } \\
\text { Faktor keluarga sebagai penentu terjadinya } \\
\text { keterlambatan pertumbuhan di Rwanda, } \\
\text { intervensi pada ibu hamil dan menyusui dapat } \\
\text { mencegah BBLR, menurunkan kemiskinan, } \\
\text { edukasi gizi pada wanita. }\end{array}$ \\
\hline $\begin{array}{l}\text { Al Paudel R } \\
\text { et al, 2012, } \\
\text { Nepal }\end{array}$ & $\begin{array}{l}\text { Faktor risikos for } \\
\text { Stunting Among } \\
\text { Children: A } \\
\text { Community Based } \\
\text { Case Control Study } \\
\text { in Nepal }\end{array}$ & $\begin{array}{l}\text { Populasi 244, } \\
\text { case } 106 \text { anak, } \\
\text { control } 106 \text { anak }\end{array}$ & $\begin{array}{l}\text { Community } \\
\text { Base-Case } \\
\text { Control }\end{array}$ & $\begin{array}{l}\text { Hasil penelitian ini yang menjadi faktor risiko } \\
\text { adalah ibu tidak bekerja }(3,11) \text {, keluarga } \\
\text { kekurangan makan }(4,826) \text {, anak diasuh oleh } \\
\text { pembantu }(3,02) \text {, dapur tanpa ventilasi. } \\
\text { Kesimpulan : } \\
\text { Stunting terjadi akibat dari faktor social } \\
\text { ekonomi, lingkungan dan praktek pemberian } \\
\text { makan yang tidak tepat. }\end{array}$ \\
\hline $\begin{array}{l}\text { Bancha } \\
\text { Batiro et al, } \\
2017, \\
\text { Ethiopia }\end{array}$ & $\begin{array}{l}\text { Determinants of } \\
\text { stunting among } \\
\text { children aged 6-59 } \\
\text { months at Kindo } \\
\text { Didaye woreda, } \\
\text { Wolaita Zone, } \\
\text { Southern Ethiopia: } \\
\text { Unmatched } \\
\text { Case Control Study }\end{array}$ & $\begin{array}{l}465 \text { kasus } 155, \\
\text { control 310, } \\
\text { anak umur 6-59 } \\
\text { bulan }\end{array}$ & Case Control & $\begin{array}{l}\text { Sumber air minum tidak aman }(7,06) \text {, ISPA } 2 \\
\text { minggu 6terakhir }(3,04), \text { IMD terlambat }(5,16) \text {, } \\
\text { Imunisasi tidak lengkap }(6,38) \text {. } \\
\text { Kesimpulan : } \\
\text { Faktor risiko stunting adalah penyakit infeksi } \\
\text { seperti diare, ISPA, keterlambatan pemberia } \\
\text { ASI, tidak imunisasi, defisiensi makanan } \\
\text { hewani, sumber air yang tidak aman. }\end{array}$ \\
\hline $\begin{array}{l}\text { Fatemeh } \\
\text { Esfarjani et } \\
\text { al, 2012, Iran }\end{array}$ & $\begin{array}{l}\text { Determinants of } \\
\text { Stunting in } \\
\text { School-Aged } \\
\text { Children of Tehran, } \\
\text { Iran }\end{array}$ & $\begin{array}{l}\text { Jumlah populasi } \\
3147 \text {, stunted : } \\
86 \text { anak, Non } \\
\text { Stunted : } 308\end{array}$ & Case Control & $\begin{array}{l}\text { Faktor risiko teerjadinya stunting adalah BBLR, } \\
\text { usia ibu }>35 \text { tahun, TB ayah }<160 \mathrm{~cm} . \\
\text { Kesimpulan : } \\
\text { Faktor risiko utama terjadinya stunting adalah } \\
\text { berat lahir, usia ibu, dan tinggi badan ayah. }\end{array}$ \\
\hline $\begin{array}{l}\text { Aryu Candra } \\
\text { et al, 2011, } \\
\text { Semarang } \\
\text { Indonesia }\end{array}$ & $\begin{array}{l}\text { Faktor risikos of } \\
\text { Stunting among 1-2 } \\
\text { Years Old Children } \\
\text { in Semarang City }\end{array}$ & $\begin{array}{l}58 \text { kasus dan } 58 \\
\text { kontrol, Anak } \\
\text { umur } 1-2 \text { tahun }\end{array}$ & Case Control & $\begin{array}{l}\text { Faktor risiko stunting dalam penelitian ini } \\
\text { adalah tinggi badan ayah }<162 \mathrm{~cm}(2,7), \mathrm{BBLR} \\
(11,2) \text {, riwayat gizi buruk }(3,3) . \\
\text { Kesimpulan : } \\
\text { Faktor risiko terjadinya stunting pada anak } 1-2 \\
\text { tahun adalah tinggi badan ayah }<162 \mathrm{~cm} \text { dan } \\
\text { mempunyai riwayat BBLR, serta berat badan } \\
\text { kurang }\end{array}$ \\
\hline $\begin{array}{l}\text { Friska } \\
\text { Meilyasari } \\
\text { dkk, 2014, } \\
\text { Kendal } \\
\text { Indonesia }\end{array}$ & $\begin{array}{l}\text { Faktor risiko } \\
\text { kejadian stunting } \\
\text { pada balita usia } 12 \\
\text { bulan di desa } \\
\text { purwokerto } \\
\text { kecamatan } \\
\text { patebon, kabupaten } \\
\text { kendal } \\
\end{array}$ & $\begin{array}{l}\text { Sampel } 48 \text { anak } \\
\text { usia } 12 \text { bulan, } \\
\text { dibagi } 2 \\
\text { kelompok kasus } \\
24 \text { dan control } \\
24\end{array}$ & Case Control & $\begin{array}{l}\text { Panjang Lahir (16,43), prematuritas }(11,5) \text {, } \\
\text { Usia makan pertama(2,06), skor MP ASI }(1,41) \text {. } \\
\text { Kesimpulan: } \\
\text { Faktor risiko kejadian stunting pada balita usia } \\
12 \text { bulan adalah panjang badan lahir rendah } \\
\text { (pendek), prematuritas dan usia makan } \\
\text { pertama terlalu dini. }\end{array}$ \\
\hline $\begin{array}{l}\text { Hiwot Yisak } \\
\text { et al, 2015, } \\
\text { Ethiopia }\end{array}$ & $\begin{array}{l}\text { Prevalence and } \\
\text { faktor risikos for } \\
\text { under nutrition } \\
\text { among children } \\
\text { under five at } \\
\text { Haramaya district, } \\
\text { Eastern Ethiopia }\end{array}$ & $\begin{array}{l}791 \text { anak di } \\
\text { bawah } 5 \text { tahun } \\
\text { yang memenuhi } \\
\text { kriteria }\end{array}$ & $\begin{array}{l}\text { A community } \\
\text { based cross } \\
\text { sectional } \\
\text { study }\end{array}$ & $\begin{array}{l}\text { Anak yang tinggal di pedesaan berisiko }(2,45) \text {, } \\
\text { usia di bawah } 6 \text { tahun }(1,9) \text {, anak yang tinggal } \\
\text { di klg miskin }(1,8) \text {, anak yang tinggal di dataran } \\
\text { rendah }(3,2) \text {, anak yang diare }(2,4) \text { BMI ibu } \\
<18,5(2,17) \text {, ibu tidak ANC }(3,4) \text {, anak yang } \\
\text { lahir ke } 4-5(3,0) \text {, anak laki-laki }(2,3) \text {. } \\
\text { Kesimpulan : } \\
\text { Penelitian ini menunjukkan bahwa anak-anak } \\
\text { di bawah lima tahun sebagian mengalami }\end{array}$ \\
\hline
\end{tabular}




\begin{tabular}{|c|c|c|c|c|}
\hline $\begin{array}{c}\text { Nama } \\
\text { peneliti }\end{array}$ & Judul Penelitian & Populasi & Metode & Hasil dan Kesimpulan \\
\hline & & & & $\begin{array}{l}\text { stunting karena riwayat gizi buruk dan } \\
\text { gangguan pertumbuhan, hal ini dapat } \\
\text { dilakukan dengan memberikan pendidikan gizi } \\
\text { khusunya pada ibu atau pengasuh untuk } \\
\text { meningkatkan status gizi anak-anak. }\end{array}$ \\
\hline $\begin{array}{l}\text { Teshale } \\
\text { Fikadu et al, } \\
\text { 2014, South } \\
\text { Ethiopia }\end{array}$ & $\begin{array}{l}\text { Factors associated } \\
\text { with stunting } \\
\text { among children of } \\
\text { age } 24 \text { to } 59 \text { months } \\
\text { in Meskan district, } \\
\text { Gurage Zone, South } \\
\text { Ethiopia: a case- } \\
\text { control study }\end{array}$ & $\begin{array}{l}\text { Anak umur 24- } \\
59 \text { bulan dengan } \\
\text { kasus } 121 \text { dan } \\
\text { control } 121 \text { anak }\end{array}$ & $\begin{array}{l}\text { Community } \\
\text { based case- } \\
\text { control study }\end{array}$ & $\begin{array}{l}\text { Anak yang tinggal dengan } 8-10 \text { anggota } \\
\text { keluarga }(4,4) \text {, anak yang tinggal dengan } 2-3 \\
\text { balita }(3,7) \text {, ibu bekerja sebagai pedagang } \\
(4,0) \text {, anak yang diberi ASI }<2 \text { tahun }(3,2) \text {, } \\
\text { anak yang minum susu formula }(3,3) \text { berisiko } \\
\text { terjadinya stunting. } \\
\text { Kesimpulan: } \\
\text { Faktor yang berhubungan dengan stunting } \\
\text { adalah ukuran keluarga, jumlah balita, } \\
\text { pekerjaan ibu, lama menyusui secara } \\
\text { eksklusif,dan metode pemberian makanan } \\
\text { pendamping. }\end{array}$ \\
\hline $\begin{array}{l}\text { Loida María } \\
\text { García Cruz } \\
\text { et al, 2017, } \\
\text { Mozambique }\end{array}$ & $\begin{array}{l}\text { Factors Associated } \\
\text { with Stunting } \\
\text { among Children } \\
\text { Aged } 0 \text { to } 59 \\
\text { Months from the } \\
\text { Central Region } \\
\text { of Mozambique }\end{array}$ & $\begin{array}{l}\text { Sampel } 282 \text { anak } \\
\text { bibawah } 5 \text { tahun } \\
\text { (162 anak laki- } \\
\text { laki, dan } 120 \\
\text { anak wanita) }\end{array}$ & $\begin{array}{l}\text { Case-Control } \\
\text { study }\end{array}$ & $\begin{array}{l}\text { Berdasarkan hasil penelitian variable Berat } \\
\text { lahir, pendidikan ibu, pekerjaan ibu, tinggal } \\
\text { didaerah pedesaan, jumlah anggota keluarga, } \\
\text { jumlah anak balita dalam rumah, memasak } \\
\text { dengan arang, rumah dari jerami, tanpa } \\
\text { lantai,durasi pemberian ASI berhubungan } \\
\text { dengan stunting. } \\
\text { Kesimpulan: } \\
\text { Dapat disimpulkan bahwa program intervensi } \\
\text { gizi yang tepat adalah tingkat pengetahuan } \\
\text { sebgai faktor penentu terjadinya masalah gizi } \\
\text { pada anak. }\end{array}$ \\
\hline $\begin{array}{l}\text { Chitale } \\
\text { Remonja } \\
\text { Rabaoarisoa } \\
\text { et al, 2017, } \\
\text { Madagascar }\end{array}$ & $\begin{array}{l}\text { The importance of } \\
\text { public health, } \\
\text { poverty reduction } \\
\text { programs and } \\
\text { women's } \\
\text { empowerment in } \\
\text { the reduction of } \\
\text { child stunting in } \\
\text { rural areas of } \\
\text { Moramanga and } \\
\text { Morondava, } \\
\text { Madagascar }\end{array}$ & $\begin{array}{l}\text { Jumlah sampel } \\
932 \text { anak, mulai } \\
\text { umur } 6-59,9 \\
\text { bulan }\end{array}$ & $\begin{array}{l}\text { A Case- } \\
\text { Control Study }\end{array}$ & $\begin{array}{l}\text { Dari hasil penelitian di moramanga diperoleh } \\
\text { infeksi Trichuris trichura berisiko } 2,4 \text { kali dan } \\
\text { keluarga miskin berisiko } 2,3 \text { kali mengalami } \\
\text { stunting. Sedangkan di Moramanga diperoleh } \\
\text { ibu bekerja diluar rumah berisiko } 1,2 \text { dan bayi } \\
\text { lahir kecil berisiko } 1,6 \text { kali mengalami stunting. } \\
\text { Kesimpulan: } \\
\text { Kegiatan intervensi untuk meningkatkan } \\
\text { pertumbuhan anak adalah mengurangi } \\
\text { kemiskinan, pemberdayaan perempuan, } \\
\text { program kesehatan masyarakat yang berfokus } \\
\text { pada WASH dan peningkatan penerimaan, dan } \\
\text { peningkatan cakupan kualitas layanan } \\
\text { kesehatan ibu dan anak. }\end{array}$ \\
\hline
\end{tabular}

Jika dilihat berdasarkan kerangka konsep WHO menunjukkan peninjauan yang menyeluruh terhadap artikel-artikel tentang determinan terjadinya stunting pada anak di Indonesia dan Negara berkembang lainya, dari hasil literature review yang kami lakukan diperoleh secara konsisten untuk variable tinngi badan ibu, kelahiran premature, BBLR, panjang badan lahir, pendidikan ibu yang rendah, penyakit infeksi, social ekonomi keluarga merupakan faktor risiko terjadinya stunting di Indonesia ${ }^{55}$, belakangan ini telah dilakukan penelitian cross sectional menunjukkan bahwa variable penyapihan ASI dini, tinggi badan ayah, konsumsi air minum yang tidak diolah, lingkungan kumuh berisiko terjadinya stunting ${ }^{56}$, sedangkan penelitian di Pulau Madura diperoleh bahwa pemberian makanan pendamping ASI terlalu dini berisiko mengalami stunting pada anak ${ }^{57}$.

Upaya mengatasi stunting tersebut telah dilakukan penelitian ekperimental dengan memberikan suplementasi zinc pada anak yang mengalami stunting untuk melihat $\mathrm{Z}$-score $\mathrm{TB} / \mathrm{U}^{58}$, terdapat perbedaan perubahan pertumbuhan linier pada balita yang mengalami stunting setelah diberikan suplementasi kalsium $^{59}$ kami juga menemukan bahwa peran komunitas dan masyarakat,akses ke pelayanan kesehatan, penyedia pelayanan kesehatan berkualitas sangat berperan penting dalam terjadinya stunting di Indonesia.

Selain dilakukan penelitian dari dunia akademisi, di Indonesia sudah dikembangkan kebijakan yaitu "Scaling up Nutrition" telah diterjemahkan kedalam Gerakan Nasional 1000 HPK. Mengingat masalah gizi 
merupakan masalah yang memiliki variabel Multi Faktorial, maka implementasinya membutuhkan keterlibatan lintas sektor. Studi mengenai keberhasilan implementasi kebijakan penurunan masalah gizi melalui berbagai metode (sistematic review, kuantitative riset, semi kualitatif interview, analisis pohon masalah) menunjukkan bahwa implementasi upaya mengatasi masalah gizi secara menyeluruh harus dilakukan walaupun banyak rintangan di lapangan ${ }^{60}$.

Indonesia telah berkomitmen untuk turut menurunkan prevalensi stunting yang masih menjadi masalah dalam kesehatan Masyarakat. Terbitnya Perpres No. 42/2013 merupakan salah satu strategi dalam SUN dengan melibatkan berbagai bidang dan unsur pemerintahan. Peraturan Presiden sangat diperlukan sebagai dasar dalam melakukan intervensi dan riset. Dalam berbagai hasil penelitian telah disebutkan bahwa penelitian tentang stunting berhubungan dengan kemiskinan, pendidikan rendah, beban penyakit, pemberdayaan perempuan yang masih rendah ${ }^{15,61}$. Studi di Bangladesh menunjukkan adanya pengaruh antara kemiskinan dengan masalah gizi kurang dan buruk yang ditemukan pada ibu buta huruf, pendapatan rendah, memiliki saudara kandung lebih banyak, rendahnya akses terhadap media,rendahnya asupan gizi, serta sanitasi dan kesehatan lingkungan yang lebih rendah berisiko terjadinya masalah gizi62 Namun demikian, kesenjangan pembangunan antar wilayah di Indonesia juga berpengaruh terhadap disparitas prevalensi stunting yang cukup lebar. Hasil studi di Ghana menyebutkan, kemiskinan dan karakteristik wilayah sebagai penyebab kesenjangan dalam masalah gizi pada anak balita ${ }^{63}$. Namun demikian, hasil studi dari negara-negara miskin dan sedang berkembang membuktikan bahwa tidak ada hubungan antara laju pertumbuhan ekonomi dengan masalah gizi kurang pada usia dini64. Oleh karena itu dibutuhkan upaya yang serius dalam penangan dan penurunan masalah stunting pada usia dini bahkan dalam 1000 HPK sebagai periode emas dalam pencegahan pertumbuhan peningkatan stunting65 Pertumbuhan tidak maksimal pada masa balita memiliki dampak jangka panjang. Bila faktor eksternal (setelah lahir) tidak mendukung, pertumbuhan stunting dapat menjadi permanen sebagai remaja pendek. Hasil-hasil penelitian menunjukkan bahwa mereka yang memiliki ukuran tubuh lebih kecil atau stunting ketika lahir, secara antropometri memiliki ukuran yang berbeda dari mereka yang lahir dengan ukuran tubuh lebih besar ${ }^{66}$. Oleh karena itu, penanggulangan masalah stunting harus dimulai jauh hari sebelum seorang anak dilahirkan (periode 1000 HPK) dan bahkan sejak masa remaja supaya dapat memutus rantai stunting dalam siklus kehidupan.

Keterbatasan dari review artikel ini hanya dapat menggambarkan faktor riskio stunting dengan menggunakan data sekunder saja, artikel yang di dapat hanya menggunakan bahasa Indonesia dan Inggris, data base pencarian yang digunakan hanya Google Scholar dan ProQuest. Kelebihan dari review ini, diantaranya belum banyak ditemukan literature review artikel tentang stunting di negara berkembang, khususnya Indonesia

\section{KESIMPULAN}

Berdasarkan hasil identifikasi dan telaah beberapa artikel dapat disimpulkan bahwa faktor risiko terjadinya stunting di negara berkembang secara konsisten adalah status social ekonomi keluarga (pendapatan keluarga), pendidikan ibu, Berat Bayi Lahir Rendah (BBLR), kelahiran prematur, pemberian ASI yang tidak eksklusif, panjang lahir, defisiensi makronutrient dan mikronutrient. Mengingat kompleknya faktor risiko terjadinya stunting, penguatan sistem program 1000 Hari Pertama Kehidupan diharapkan dapat dikembangkan menjadi bagian dari budaya dan kehidupan sosial di masyarakat sehingga intervensi yang dilakukan dapat berkesimbungan.

\section{ACKNOWLEDGMENT}

Penulis mengucapkan terimakasih kepada dosen Program Doktor di Universitas Diponegoro atas masukan dan saran dalam penyusunan dan penyelesaian penulisan literature review ini.

\section{REFERENSI}

1. Grantham-McGregor, S. M., Walker, S. P., Himes, J. H. \& Powell, C. A. Stunting and mental development in children. Nutr. Res. 16, 18211828 (1996).

2. Tables, S. Levels and Trends in Child Malnutrition, 1990 -. 9-13 (2015).

3. Hagos, S., Hailemariam, D., WoldeHanna, T. \& Lindtjørn, B. Spatial heterogeneity and risk factors for stunting among children under age five in Ethiopia: A Bayesian geo-statistical model. PLoS One 12, 1-19 (2017).

4. Bogale, T. Y., Bala, E. T., Tadesse, M. \& Asamoah, B. O. Prevalence and associated factors for stunting among 6-12 years old school age children from rural community of Humbo district, Southern Ethiopia. BMC Public Health 1-9 (2018). doi:10.1186/s12889-0185561-z

5. Senbanjo, I. O., Oshikoya, K. A., Odusanya, O. O. \& Njokanma, O. F. Prevalence of and Risk factors for Stunting among School Children and Adole...: EBSCOhost. J. Heal. Popul. Nutr. 29, 364-370 (2011).

6. Copy of API_SH.

7. Ministry, R. H. Hasil Utama Laporan Riskesdas 2018. (2018).

8. Calkins, K. \& Devaskar, S. U. Fetal Origins of Adult Disease Kara. Curr Probl Pediatr Adolesc Heal. Care 41, 158-176 (2011).

9. Sari, M. et al. Higher Household Expenditure on Animal-Source and Nongrain Foods Lowers the Risk of Stunting among Children 0-59 Months Old in Indonesia: Implications of Rising Food Prices. J. Nutr. 140, 195S-200S (2010).

10. Kyu, H. H., Georgiades, K. \& Boyle, M. Maternal smoking, biofuel smoke exposure and child height-for-age in seven developing countries. 
Int. J. Epidemiol. 38, 1342-1350 (2009).

11. de Onis, M. \& Onyango, A. W. $\{\mathrm{WHO}\}$ child growth standards. Lancet 371, 204 (2008).

12. Fikadu, T., Assegid, S. \& Dube, L. Factors associated with stunting among children of age 24 to 59 months in Meskan district, Gurage Zone, South Ethiopia: A case-control study. BMC Public Health 14, 1-7 (2014).

13. Paramashanti, B. A., Hadi, H. \& Gunawan, I. M. A. Pemberian ASI eksklusif tidak berhubungan dengan stunting pada anak usia 6-23 bulan di Indonesia. J. Gizi dan Diet. Indones. (Indonesian J. Nutr. Diet. 3, 162 (2016).

14. Aryastami, N. K. \& Tarigan, I. Kajian Kebijakan dan Penanggulangan Masalah Gizi Stunting di Indonesia. Bul. Penelit. Kesehat. 45, 233-240 (2017).

15. De Onis, M., Onyango, A. W., Borghi, E., Garza, C. \& Yang, H. Comparison of the World Health Organization (WHO) Child Growth Standards and the National Center for Health Statistics/WHO international growth reference: Implications for child health programmes. Public Health Nutr. 9, 942-947 (2006).

16. RISKESDAS. Riset Kesehatan Dasar. Kementeri. Kesehat. Republik Indones. 1-384 (2013). doi:1 Desember 2013

17. Presiden ajak Bank Dunia atasi stunting.

18. Torlesse, H., Cronin, A. A., Sebayang, S. K. \& Nandy, R. Determinants of stunting in Indonesian children: Evidence from a crosssectional survey indicate a prominent role for the water, sanitation and hygiene sector in stunting reduction. BMC Public Health 16, 1-11 (2016).

19. Rachmi, C. N., Agho, K. E., Li, M. \& Baur, L. A. Stunting, underweight and overweight in children aged 2.0-4.9 years in Indonesia: Prevalence trends and associated risk factors. PLoS One 11, 1-18 (2016).

20. Hadi, H., Julia, M. \& Herman, S. ARTIKEL DEFISIENSI VITAMIN A DAN ZINC SEBAGAIFAKTOR RISIKO TERJADINYA STUNTING PADA BALITA DI NUSA TENGGARA BARAT. XIX, (2009).

21. Wellina, W. F., Kartasurya, M. I. \& Rahfilludin, M. Z. Faktor risiko stunting pada anak umur 1224 bulan. J. Gizi Indones. 5, 55-61 (2016).

22. Bentian, I. \& Rattu, N. M. A. J. M. Faktor Resiko Terjadinya Stunting Pada Anak TK Di Wilayah Kerja Puskesmas Siloam Tamako Kabupaten Kepulauan Sangihe Propinsi Sulawesi Utara Risk factors for stunting in children kindergarten in Puskesmas Siloam Tamako Sangihe Islands of North Sulawesi Province. 1-7

23. Rachmi, C. N., Hunter, C. L., Li, M. \& Baur, L. A. Food choices made by primary carers (mothers/ grandmothers) in West Java, Indonesia. Appetite 130, 84-92 (2018).

24. Lestari, W., Margawati, A. \& Rahfiludin, M. Z. Faktor risiko stunting pada anak umur 6-24 bulan di kecamatan Penanggalan kota
Subulussalam provinsi Aceh. 3, 37-45 (2014).

25. Geberselassie, S. B., Abebe, S. M., Melsew, Y. A., Mutuku, S. M. \& Wassie, M. M. Prevalence of stunting and its associated factors among children 6-59 months of age in Libo-Kemekem district, Northwest Ethiopia; A community based cross sectional study. PLoS One 13, 1-12 (2018).

26. Reyes, H. et al. The family as a determinant of stunting in children living in conditions of extreme poverty: A case-control study. $B M C$ Public Health 4, 1-10 (2004).

27. Kurnia Illahi, R. Hubungan Pendapatan Kelarga, Berat Lahir, dan Panjang Lahir dengan Kejadian Stunting balita 24-59 bulan di Bangkalan. Manaj. Kesehat. Yayasan RS Dr. Sietomo 3, 1-14 (2017).

28. Nadiyah. Faktor Risiko Stunting Pada Anak Usia 0-23 Bulan Di Provinsi Bali, Jawa Barat, Dan Nusa Tenggara Timur. J. Gizi dan Pangan 9, 125-132 (2014).

29. Al-Anshori, H. \& Nuryanto, N. FAKTOR RISIKO KEJADIAN STUNTING PADA ANAK USIA 12-24 BULAN (Studi di Kecamatan Semarang Timur). J. Nutr. Coll. 2, 675-681 (2013).

30. Agho, K. E., Inder, K. J., Bowe, S. J., Jacobs, J. \& Dibley, M. J. Prevalence and risk factors for stunting and severe stunting among under-fives in North Maluku province of Indonesia. 10, 1-10 (2009).

31. Blair, P. et al. Socio-demographic correlates of stunting among children. 5, 4231-4236 (2018).

32. Paudel, R., Pradhan, B., Wagle, R. R., Pahari, D. P. \& Onta, S. R. Risk factors for stunting among children: A community based case control study in Nepal. Kathmandu Univ. Med. J. 10, 18-24 (2012).

33. Yisak, H., Gobena, T. \& Mesfin, F. Prevalence and risk factors for under nutrition among children under five at Haramaya district, Eastern Ethiopia. BMC Pediatr. 1-7 (2015). doi:10.1186/s12887-015-0535-0

34. Rabaoarisoa, C. R. et al. The importance of public health, poverty reduction programs and women's empowerment in the reduction of child stunting in rural areas of Moramanga and Morondava, Madagascar. PLoS One 12, 1-19 (2017).

35. Shine, S., Tadesse, F., Shiferaw, Z., Mideksa, L. \& Seifu, W. Prevalence and Associated Factors of Stunting among 6-59 Months Children in Pastoral Community of Korahay Zone, Somali Regional State, Ethiopia 2016. J. Nutr. Disord. Ther. 07, 1-8 (2017).

36. Nshimyiryo, A. et al. Risk factors for stunting among children under five years: a crosssectional population-based study in Rwanda using the 2015 Demographic and Health Survey. 1-10 (2019).

37. Candra, A. Suplementasi mikronutrien dan penanggulangan malnutrisi pada anak usia di bawah lima tahun (balita). Jnh 5, 8 (2017). 
38. Aryastami, N. K. et al. Low birth weight was the most dominant predictor associated with stunting among children aged 12-23 months in Indonesia. BMC Nutr. 3, 16 (2017).

39. Rahayu, A., Yulidasari, F., Putri, A. O. \& Rahman, F. Riwayat Berat Badan Lahir dengan Kejadian Stunting pada Anak Usia Bawah Dua Tahun. Kesmas Natl. Public Heal. J. 10, 67 (2015).

40. Tiwari, R., Ausman, L. M. \& Agho, K. E. Determinants of stunting and severe stunting among under-fives: evidence from the 2011 Nepal Demographic and Health Survey. 1-15 (2014).

41. Esfarjani, F., Roustaee, R., Mohammadi, F. \& Esmaillzadeh, A. Determinants of stunting in school-aged children of Tehran, Iran. Int. J. Prev. Med. 4, 173-179 (2013).

42. Candra, A. \& Puruhita, N. MEDIA MEDIKA. 45, 206-212 (2011).

43. Aguayo, V. M., Nair, R., Badgaiyan, N. \& Krishna, $\mathrm{V}$. Determinants of stunting and poor linear growth in children under 2 years of age in India: An in-depth analysis of Maharashtra's comprehensive nutrition survey. Matern. Child Nutr. 12, 121-140 (2016).

44. Isnaini, F. \& Indrawani, Y. M. Faktor Dominan Penyebab Stunting Usia 12-23 Bulan di Posyandu Terpilih Kelurahan Depok Tahun 2014. 1-19 (2014).

45. Patebon, P. K., Kendal, K. \& Kendal, K. Online di : http://ejournal-s1.undip.ac.id/index.php/jnc Journal of Nutrition College, Volume 3 , Nomor 2 , Tahun 2014 , Halaman. 3, 26-32 (2014).

46. Nkurunziza, S., Meessen, B., Van geertruyden, J. P. \& Korachais, C. Determinants of stunting and severe stunting among Burundian children aged 6-23 months: Evidence from a national crosssectional household survey, 2014. BMC Pediatr. 17, 1-15 (2017).

47. Kartono, D., Fuada, N. \& Setyawati, B. Stunting anak usia sekolah di Indonesia... (Salimar; dkk) STUNTING. 36, 121-126 (2013).

48. Mazengia, A. L. Predictors of Stunting among School-Age Children in Northwestern Ethiopia. 2018, (2020).

49. Sarma, H. et al. Factors Influencing the Prevalence of Stunting Among Children Aged Below Five Years in Bangladesh. 38, 291-301 (2017).

50. Berhanu, G., Mekonnen, S. \& Sisay, M. Prevalence of stunting and associated factors among preschool children: A community based comparative cross sectional study in Ethiopia. BMC Nutr. 4, 28 (2018).

51. S., B., S., S. \& W., L. Determinants of child malnutrition during the 1999 economic crisis in selected poor areas of Indonesia. Asia Pac. J. Clin. Nutr. 16, 512-526 (2007).

52. Batiro, B., Demissie, T., Halala, Y. \& Anjulo, A. A. Determinants of stunting among children aged 6-59 months at Kindo Didaye woreda, Wolaita Zone, Southern Ethiopia: Unmatched case control study. PLoS One 12, 1-16 (2017).

53. Akombi, B. J. et al. Stunting and severe stunting among children under-5 years in Nigeria: $A$ multilevel analysis. BMC Pediatr. 17, 1-17 (2017).

54. Rabaoarisoa, C. R. et al. The importance of public health, poverty reduction programs and women' $s$ empowerment in the reduction of child stunting in rural areas of Moramanga and. 1-18 (2017). doi:10.1371/journal.pone.0186493

55. Beal, T., Tumilowicz, A., Sutrisna, A., Izwardy, D. \& Neufeld, L. M. A review of child stunting determinants in Indonesia. Matern. Child Nutr. 14, 1-10 (2018).

56. Hwalla, N. et al. The prevalence of micronutrient deficiencies and inadequacies in the middle east and approaches to interventions. Nutrients 9, 1-29 (2017).

57. Illahi, R. K. \& Muniroh, L. Gambaran Sosio Budaya Gizi Etnik Madura. Media Gizi Indones. 11, 135-143 (2016).

58. Pertiwi, D., Kusudaryati, D., Muis, S. F. \& Widajanti, L. Pengaruh suplementasi Zn terhadap perubahan indeks TB / $\mathrm{U}$ anak stunted usia 24-36 bulan. J. Gizi Indones. 5, 98-104 (2017).

59. Saraswati E dan Budiman B. Dampak Suplementasi Makanan Berkalsium Terhadap Pertumbuhan Tulang Anak Umur 9-11 Bulan. Pgm 5-15 (1999).

60. Morris, S. S., Cogill, B. \& Uauy, R. Effective international action against undernutrition: why has it proven so difficult and what can be done to accelerate progress? Lancet 371, 608-621 (2008).

61. Keats, E. C., Imdad, A., Das, J. K. \& Bhutta, Z. A. Protocol: Efficacy and effectiveness of micronutrient supplementation and fortification interventions on the health and nutritional status of children under-five in low and middleincome countries : a systematic review. (2018).

62. Shafiur Rahman, M. et al. Under Weightiness among Ever-married Non-pregnant Women in Bangladesh: A Population Based Study. Univers. J. Food Nutr. Sci. 3, 29-36 (2015).

63. Atsu, B. K., Guure, C. \& Laar, A. K. Determinants of overweight with concurrent stunting among Ghanaian children. BMC Pediatr. 17, 1-12 (2017).

64. Vollmer, S. et al. Association between economic growth and early childhood undernutrition: Evidence from 121 Demographic and Health Surveys from 36 low-income and middle-income countries. Lancet Glob. Heal. 2, 225-234 (2014).

65. De Onis, M., Blössner, M. \& Borghi, E. Prevalence and trends of stunting among preschool children, 1990-2020. Public Health Nutr. 15, 142-148 (2012).

66. Krebs, N. F. Update on zinc deficiency and excess in clinical pediatric practice. Ann. Nutr. Metab. 62, 19-29 (2013). 